\title{
Znanstveno-istraživačka djelatnost Zavoda za organsku kemiju u razdoblju 2009. - 2019.
}

\section{T. Gazivoda Kraljević, M. Hranjec, S. Raić-Malić, I. Škorić i D. Vuk*}

Zavod za organsku kemiju, Fakultet kemijskog inženjerstva i tehnologije,

Sveučilište u Zagrebu, Marulićev trg 20, Zagreb

\section{Sažetak}

Od osnutka Zavoda za organsku kemiju Fakulteta kemijskog inženjerstva i tehnologije Sveučilišta u Zagrebu, koji je 1922 . god. osnovao prof. dr. Ivan Marek, te kasnije preko djelovanja nobelovca Vladimira Preloga i brojnih uspješnih generacija organskih kemičara, vidljiv je utjecaj ne samo na znanstvenu djelatnost Zavoda nego i na cjelokupnu hrvatsku kemijsku zajednicu, osobito u području organske sintetske i medicinske kemije. Preparativnu organsku kemiju profesor Prelog držao je nužnom odrednicom studija, koja je zahvaljujući njegovu djelovanju u Zavodu (1935. - 1941.) ostala glavna okosnica znanstveno-istraživačkog rada. Od samog osnivanja u laboratorijima Zavoda odvijaju se istraživanja iz područja sintetske organske i medicinske kemije i fotokemije, stječu se znanstveni stupnjevi i obrazuju brojni organski kemičari, među kojima su danas mnogi priznati znanstvenici u Hrvatskoj i svijetu.

\section{Ključne riječi}

Zavod za organsku kemiju, sintetska organska kemija, medicinska kemija, organska fotokemija

\section{Uvod}

Zavod za organsku kemiju Fakulteta kemijskog inženjerstva i tehnologije Sveučilišta u Zagrebu ima dugogodišnju tradiciju i ekspertizu u znanstvenim istraživanjima na polju sintetske organske kemije, koju je utemeljio sam dobitnik Nobelove nagrade profesor Vladimir Prelog. Njegov istaknut znanstveni rad uspješno su nastavile generacije priznatih znanstvenika u Hrvatskoj a entuzijazam prema preparativnoj organskoj kemiji zadržan je u Zavodu do danas. Priprava novih biološki aktivnih spojeva provodi se uz konvencionalne metode i modernim sintetskim postupcima poput reakcija potpomognutih mikrovalnim i UV zračenjem, fotokatalitičkim, mehanokemijskim i reakcijama unakrsnog spajanja te klik-kemijom i protočnim reakcijama u mikroreaktoru. Osim temeljnih istraživanja i inovativnog pristupa sintetskoj organskoj kemiji, jedan od ciljeva Zavoda je i prijenos stečenih znanja na primijenjena istraživanja, što je omogućilo stvaranje snažne jezgre na polju medicinske kemije i fotokemije ne samo na Fakultetu kemijskog inženjerstva i tehnologije već i Hrvatskoj.

\section{Znanstvena istraživanja na Zavodu za organsku kemiju}

Posljednjih 10 godina znanstvena istraživanja zaposlenika Zavoda provode se u sklopu osam domaćih i četiri međunarodna znanstvena projekta. $U$ tom razdoblju djelatnici Zavoda za organsku kemiju objavili su više od 160 znanstvenih radova iz selekcije Current Contents, 5 radova u drugim časopisima, 4 patenta, 4 knjige te su sudjelovali s

*Autor za dopisivanje: doc. dr. sc. Dragana Vuk, e-pošta: dvuk@fkit.hr više od 120 posterskih priopćenja na domaćim i međunarodnim skupovima. Djelatnici Zavoda za organsku kemiju trenutačno su angažirani na dvama znanstveno-istraživačkim projektima financiranim od strane Hrvatske zaklade za znanost.

- prof. dr. sc. Silvana Raić-Malić, izv. prof. dr. sc.

Tatjana Gazivoda Kraljević, dr. sc. Andrijana Mešćić, dr. sc. Silvija Korunda, Ivana Sokol, mag. appl. chem., Valentina Rep, mag. appl. chem.

Istraživanja u sklopu projekta Novi spojevi temeljeni na bioizosterima purina za ispitivanje njihovog antitumorskog $i$ antipatogenog djelovanja, HRZZ-IP-2018-01-4682, (voditeljica prof. dr. sc. Silvana Raić-Malić) usmjerena su na dizajniranje i sintezu novih kemijskih entiteta temeljenih na purinomimeticima s poboljšanim antitumorskim i antipatogenim djelovanjem i manjom toksičnošću s ciljem pronalaženja predvodnih spojeva koji u daljnjem razvoju mogu doprinijeti borbi protiv razvoja rezistentnosti tumorskih stanica, patogenih bakterija i protozoa. Rezistentnost na lijekove općenito predstavlja glavnu prepreku u uspješnoj kemoterapiji jer smanjuje učinkovitost postojećih lijekova. Tako je u 2015. godini rak uzrokovao više od 8,7 milijuna smrtnih slučajeva na globalnoj razini. Pretpostavlja se da će do 2020. godine broj novih oboljenja od raka u svijetu porasti na više od 15 milijuna a smrtnost se povećati na 12 milijuna. Osim toga, sve veća učestalost bolničkih infekcija, kao i onih stečenih u zajednici, koje su uzrokovane višestruko rezistentnim bakterijama (MDR) smanjuju djelotvornost antibiotske terapije. U slučaju zanemarenih tropskih bolesti, poput humane afričke tripanosomijaze (HAT), poznate i kao bolest spavanja, procjenjuje se da je preko 30 milijuna ljudi izloženo riziku od infekcije HAT-om u više od 30 afričkih zemalja. Kako bi se prevladali nastali problemi rezistencije, za sigurniju i dostupniju terapiju potrebno je razviti nove antitumorske i antipatogene lijekove. 
S ciljem razvoja novih spojeva sa snažnim i selektivnim biološkim djelovanjem primjenjuje se strategija dizajniranja lijekova, poput bioizosterije i izmjene skeleta kod kojih se atomi dušika u aromatskom prstenu zamjenjuju atomom ugljika ili drugim heteroatomom. Derivati strukturno srodni purinima povezuju se s drugom farmakofornom jedinicom preko različitih premosnica kako bi se odredio njihov utjecaj na interakciju s molekulskom metom, a time i na biološku aktivnost. Radi ispitivanja moguće prednosti održivih sintetskih metoda u odnosu na tradicionalni pristup, uz klasične sintetske metode izabranih reakcija, provode se i nekonvencionalne, poput mehanokemijskih i protočnih reakcija u mikroreaktoru. Sukladno tome, osim primjene mikrovalnog i ultrazvučnog zračenja kao neklasičnih pristupa, pokazali smo da hibridni sustav primjene ultrazvuka i kontinuiranog protoka ubrzava vrijeme provođenja reakcije od nekoliko sati pri klasičnim sintezama do svega nekoliko minuta u mikroprotočnom uređaju, uz značajno poboljšanje iskorištenja sinteze derivata L-askorbinske kiseline. ${ }^{1}$ Nadalje, potaknuti našim novijim saznanjima o klik-kemiji kataliziranoj bakrom za pripravu kinolin-1,2,3-triazolnih hibrida, bez primjene otapala, i praćenjem tijeka procesa mljevenja Ramanovom spektroskopijom upotrebom Cu(II), $\mathrm{Cu}(\mathrm{I})$ i $\mathrm{Cu}(0)$ katalizatora, ${ }^{2}$ provode se održive i ekološki prihvatljive mehanokemijske reakcije u sintezi odabranih novih spojeva. U sintezi 5,6-disupstituiranih fuzioniranih pirimidina, kao analoga purina, prvi put je opisana tandemska dimerizacija terminalnih alkina te potom 5-endo-trig ciklizacija, Sonagashira-inim paladij/bakrom-kokataliziranim unakrsnim povezivanjem. ${ }^{3}$ Iz te je serije 5,6-disupstituirani furo[2,3-d]pirimidin-2-on supstituiran ciklopropilnom skupinom pokazao najizraženije citostatsko djelovanje na karcinom jetre (HepG2) i karcinom grlića maternice (HeLa) i bolje djelovanje od lijeka 5-fluoruracila. Vezano uz inhibiciju proteinskih kinaza, pronađeno je da je citostatski učinak pirimidin-2,4-dion-1,2,3-triazolnog hibrida na HepG2 stanice povezan s inhibicijom kinaze Wee-1 i prekidom signalnog puta sfingolipida posredovanog kiselom ceramidazom i sfingozin-kinazom 1 (SK1). ${ }^{3}$ Također je pronađeno da su dobiveni antiprolife- rativni i antiapoptotički učinci derivata benzimidazola s hidrofobnim p-klorfenilnim prstenom u nemalim stanicama karcinoma pluća A549 povezani s inhibicijom specifičnih receptora plazmatskih membrana, što dovodi do blokade signalizacije p38 MAP kinazom i transkripcijskog faktora NF-кb. ${ }^{4}$ Osim toga, spoj s bis-pirolo[2,3-d]pirimidinskom (7-deazapurinskom) okosnicom povezan preko aromatske di(1,2,3-triazolil)fenil poveznice pokazao je snažan antiproliferativni učinak u nM području na karcinom gušterače (CFPAC-1), koji se može pripisati inhibiciji CDK9/ciklin T1 i slabljenju onkogene signalizacije posredovane c-Raf i p38 MAP kinazama. ${ }^{5} \mathrm{U}$ novijim istraživanjima razvijeni su amidino-2-supstituirani benzimidazoli povezani s 1,4-disupstituiranim 1,2,3-triazolima s aromatskim hidrofobnim ostatkom koji su pokazali selektivno i snažno citostatsko djelovanje na nemale stanice karcinoma pluća (A549) u niskom nM području. Citostatsko djelovanje imidazolinskog i $\mathrm{N}$-izopropilamidinskog derivata benzimidazola pripisano je smanjenju aktivnosti sfingozin-kinaze (SK1) i posebice p38 MAPK. ${ }^{6}$ Odabranim spojevima ispitana je antibakterijska i antiprotozoalna aktivnost. Tako su među hibridima heterocikla i kumarina spojevi s p-pentilfenilnom, 2-klor-4-fluorbenzensulfonamidnom i ditiokarbamatnom jedinicom snažno inhibirali rast klinički izolirane Enterococcus faecium rezistentne na vankomicin. ${ }^{7}$ Nedavno je utvrđeno da su među derivatima amidinobenzimidazola povezanim $\mathrm{s}$ hidrofobnom jedinicom preko fenoksimetilena, o-klorfenil-1,2,3-triazol i $\mathrm{N}$-izopropilamidin poboljšali djelovanje na rezistentne gram-pozitivne bakterije, posebice na soj MRSA. Nadalje, nesupstituirani amidinski i fenilni prsten uzrokovao je snažniji antibakterijski učinak na gram-negativnu $E$. coli rezistentnu na $\beta$-laktamske antibiotike od ceftazidima i ciprofloksacina. Rezultati dobiveni UV-Vis i CD spektroskopijom, kao i termičkom denaturacijom polinukleotida pokazali su dobru korelaciju antibakterijske aktivnosti spojeva i njihovih afiniteta prema ctDNA, iz čega proizlazi da je vezivanje spojeva u mali utor dominantan način vezivanja. ${ }^{8} \mathrm{U}$ istraživanju se koordinirano provodi sinteza i optimiranje struktura, zajedno s metodama dizajniranja spojeva i ispitivanja njihovih bioloških dje-

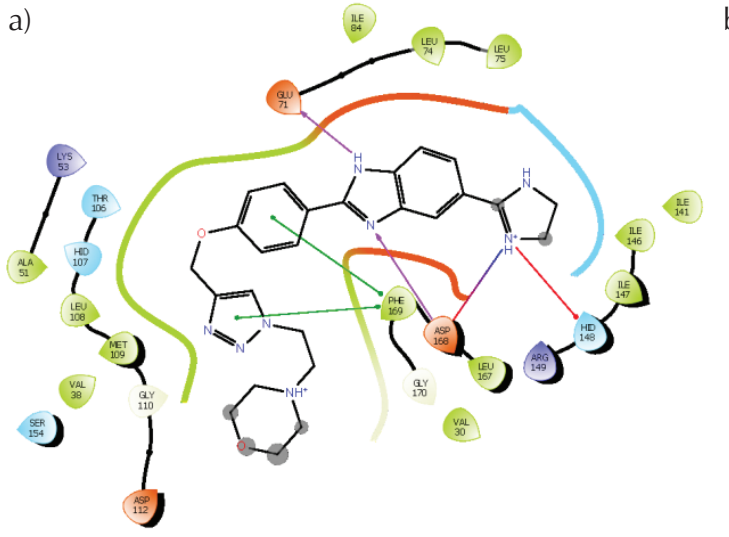

b)

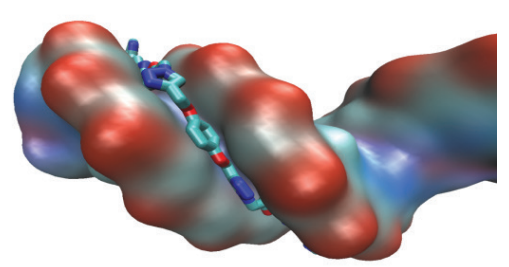

Slika 1 - a) 2D prikaz predviđenog vezivnog mjesta s naznačenim interakcijama 5-imidazolinbenzimidazola s p38 MAPK; b) derivat bis-(benzimidazol-furil-azola) vezan u mali utor dodekamera d[(CGCGAATTCGCG) $]_{2}$

Fig. 1 - a) 2D diagram of predicted binding pose with indicated interactions of 5-imidazoline benzimidazole with p38 MAPK; b) bis-(benzimidazole-furyl-azole) derivative bound into the minor groove of dodecamer $\mathrm{d}\left[(\text { CGCGAATTCGCG) }]_{2}\right.$ 
lovanja. Primjenjuju se in silico probir molekula za biološka ispitivanja in vitro i odnos biološke aktivnosti i struktura te svojstava sintetiziranih spojeva. Nadalje, za optimiranje odgovarajuće apsorpcije, raspodjele, metabolizma i izlučivanja te toksičnosti (ADMET) predviđaju se i optimiraju odgovarajuća fizikalno-kemijska svojstva novosintetiziranih spojeva. Budući da smo pronašli da amidinobenzimidazolni spojevi inhibiraju p38 MAP kinazu, ${ }^{6}$ analizirana je sposobnost vezanja njihovih strukturnih analoga za ATP-vezno mjesto p38 MAP kinaze (slika 1a). Rezultati su ukazali na dobro strukturno podudaranje i preklapanje glavnih farmakofornih točaka u novosintetiziranim spojevima. Nadalje, predstavnici derivata bis-(benzimidazol-2-il-fur-5-il-azola) dobro pristaju u mali utor DNA modela i zauzimaju uzvojitu (helikalnu) topologiju što se podudara sa zakrivljenošću malog utora DNA (slika 1b). ${ }^{9}$

$\mathrm{Na}$ temelju rezultata bioloških ispitivanja, ciljanim se strukturnim modifikacijama optimiraju strukture odabranih spojeva kandidata u svrhu poboljšanja njihovih ADMET svojstva i biološke aktivnosti. ${ }^{10-13}$ Očekujemo da će u konačnici istraživanje na navedenom projektu HRZZ-IP-2018-01-4682 rezultirati novim predvodnim spojevima sa selektivnim i učinkovitim citostatskim, odnosno antipatogenim djelovanjem, koji neće biti toksični i koji će zadovoljiti potrebne kriterije za sljedeću fazu optimiranja predvodnog spoja.

\section{- prof. dr. sc. Marijana Hranjec, Anja Beč, mag. appl. chem., Ida Boček, mag. appl. chem.}

Na projektu pod nazivom Istraživanje antioksidativnog djelovanja benzazolskog skeleta u dizajnu novih antitumorskih agensa, HRZZ-IP-2018-01-4379, čija je voditeljica prof. dr. sc. Marijana Hranjec, istraživanja su usmjerena na dizajn i razvoj novih i učinkovitih derivata benzazola kao antioksidansa s antitumorskom aktivnošću koji bi mogli biti dio antitumorske terapeutske strategije temeljene na inhibiciji ROS-a. Heterocikličke molekule su prepoznate kao privilegirane strukture u području medicinske kemije i dokazano imaju iznimno važnu ulogu u sintezi obećavajućih budućih kandidata za lijekove zbog svoje raznolike sposobnosti vezanja na različite biološke mete. Optimiranje malih organskih molekula često zahtijeva istodobno poboljšanje različitih svojstava, koja se mogu postići zamjenom izvorne kemijske strukture s novim kemijskim oblicima ili uvođenjem drugih supstituenata. Unutar različitih tipova heterocikličkih spojeva benzazolski skelet je jedan iz grupe dušikovih heterocikličkih spojeva s najvećim značajem, kao važan osnovni strukturni oblik koji je prisutan u različitim bioaktivnim prirodnim spojevima, kao i velikom broju sintetskih medicinskih i biokemijskih supstancija koje posjeduju različita važna kemijska i farmakološka svojstva. Važno je spomenuti da zbog strukturne sličnosti benzazolskih jezgri s prirodno prisutnim nukleotidima, takvi derivati imaju važnu ulogu u funkcioniranju mnogih značajnih bioloških molekula, koje mogu lagano ući u interakciju s biomolekulama u živim organizmima. Dodatno, postoji stalan rastući interes za sintezom i biološkim istraživanjima supstituiranih benzazola upravo zbog njihovog dobro poznatog $\mathrm{i}$ širokog spektra različitih i izvrsnih bioloških svojstava, kao što su antitumorska, antimikrobna, antivirusna, antioksi- dativna, antihistaminična, protuupalna, antihipertenzivna, antifugalna i druga. Noviji pristup u strategijama antitumorske terapije uključuje inhibiciju reaktivnih kisikovih čestica (ROS) jer je dobro poznato da oksidativni stres i oštećenja sudjeluju u svim stupnjevima kemijske karcinogeneze. Oksidativni stres predstavlja povećanu proizvodnju slobodnih radikala, koji uključuju vodikov peroksid, dušikov oksid, hidroksilne i peroksinitritne radikale ili superoksidne anione, koji mogu izazvati oštećenja različitih staničnih makromolekula, poput DNK, proteina i lipida. Dokazano je da postoji uključenost slobodnih radikala u signalnim putevim stanica u više kroničnih bolesti, kao što su dijabetes, ateroskleroza, infarkt miokarda, artritis, upalni procesi, neurodegenerativne bolesti i karcinogeneza. Posljednjih godina postalo je očito da, u usporedbi s normalnim stanicama, mnoge vrste stanica raka imaju povećanu razinu ROS-a, kao što su stanice leukemije, stanice gušterače, tumori štitnjače, stanice raka pluća i stanice raka prostate. Umjereno povećanje ROS-a može inducirati proliferaciju stanica i diferencijaciju, dok prekomjerne količine ROS-a mogu uzrokovati oksidacijsko oštećenje i povezuje ih se s abnormalnim rastom stanica raka.

U okviru predloženog projekta glavna pažnja usmjerena je na sintezu i biološku aktivnost novih derivata benzazola, uključujući različite derivate benzimidazola, benzotiazola, benzoksazola i imidazo[4,5-b]piridina s različitim odabranim supstituentima koji mogu imati snažan utjecaj na njihovu antioksidativnu i antitumorsku aktivnost. Kao dio dugogodišnjeg traženja novih potencijalnih biološki aktivnih, uglavnom antitumorskih agensa vezanim uz heterocikličke derivate, biološka istraživanja ranije pripravljenih spojeva u ovoj istraživačkoj skupini potvrdila su snažan i obećavajući biološki potencijal različitih derivata benzimidazola, benzotiazola i imidazo[4,5-b] piridina. Nedavno je objavljena sinteza i snažna inhibicijska aktivnost na nekoliko staničnih linija humanih karcinoma različitih aromatskih i heteroaromatskih amidino, nitro, amino i cijano supstituiranih derivata benzazola i njihovih cikličkih analoga, benzimidazo[1,2-a]kinolina. ${ }^{14-17}$ Također je potvrđeno da supstituenti bočnih lanaca smješteni na različitim položajima tetracikličkog skeleta mogu značajno promijeniti biološku aktivnost i dodatno poboljšati interakciju s biološkim metama. ${ }^{18}$ Budući da kombinacija benzimidazolske jezgre s drugim heteroaromatskim jezgrama vodi do nastanka visoko konjugiranih planarnih benzanuliranih benzimidazola s poboljšanim biološkim svojstvima, pozornost je usmjerena i na sintezu benzimidazo[1,2-a]kinolina. ${ }^{19}$ Osim njihove biološke aktivnosti, njihov izraženi intenzitet fluorescencije i mogućnost interakcije s biomakromolekulama ukazuju na potencijalnu upotrebu takvih derivata kao fluorescentnih boja za detekciju biološki važnih molekula poput DNK ili proteina u biomedicinskoj dijagnostici. ${ }^{20-22}$ Nadalje, pentacikličkim derivatima benzimidazola s aminskim lancima na različitim položajima određena je biološka aktivnost $2 \mathrm{D}$ i 3D testovima na humanim stanicama raka dojke kako bi se usporedila aktivnost s aktivnošću tetracikličkih analoga. ${ }^{23}$ Triciklički pirido[1,2-a]benzimidazoli supstituirani s amidnim bočnim lancima dizajnirani su i sintetizirani kako bi se odredila njihova antiproliferativna i antioksidativna aktivnost te su potvrđene izražene redukcijske karakteristike i uklanjanje slobodnih radikala kod više derivata. ${ }^{24}$ Nedavno je objavljen i značajan antitumorski potencijal različitih 


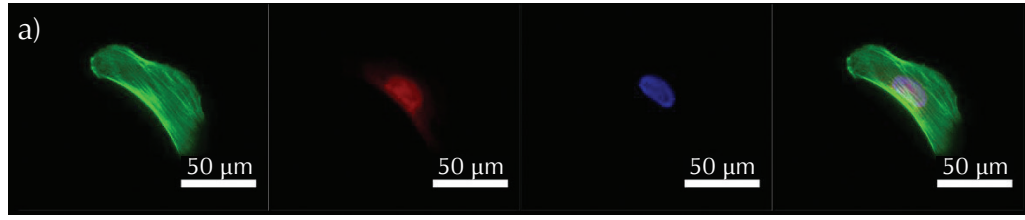<smiles>[X][M]1=NCCN1c1ccc2nc(NC(=O)c3sc4cc(C5=NCCN5)ccc4c3Cl)[nH]c2c1</smiles>

Slika 2 - Nuklearna lokalizacija bis-amidina benzimidazola (plavo) koji se selektivno veže u A-T područje DNK snimljena fluorescencijskom mikroskopijom u 786-O ccRCC staničnoj liniji korištenjem faloidina (zeleno) u citoplazmi i propidijeva jodida (crveno)cu jezgri

Fig. 2 - Nuclear localisation of benzimidazole bis-amidine (blue) which selectively binds to the A-T region of DNA evidenced by fluorescence microscopy in 786-O ccRCC cell line by using phalloidin (green) in cytoplasma and propidium iodide (red) in the nucleus
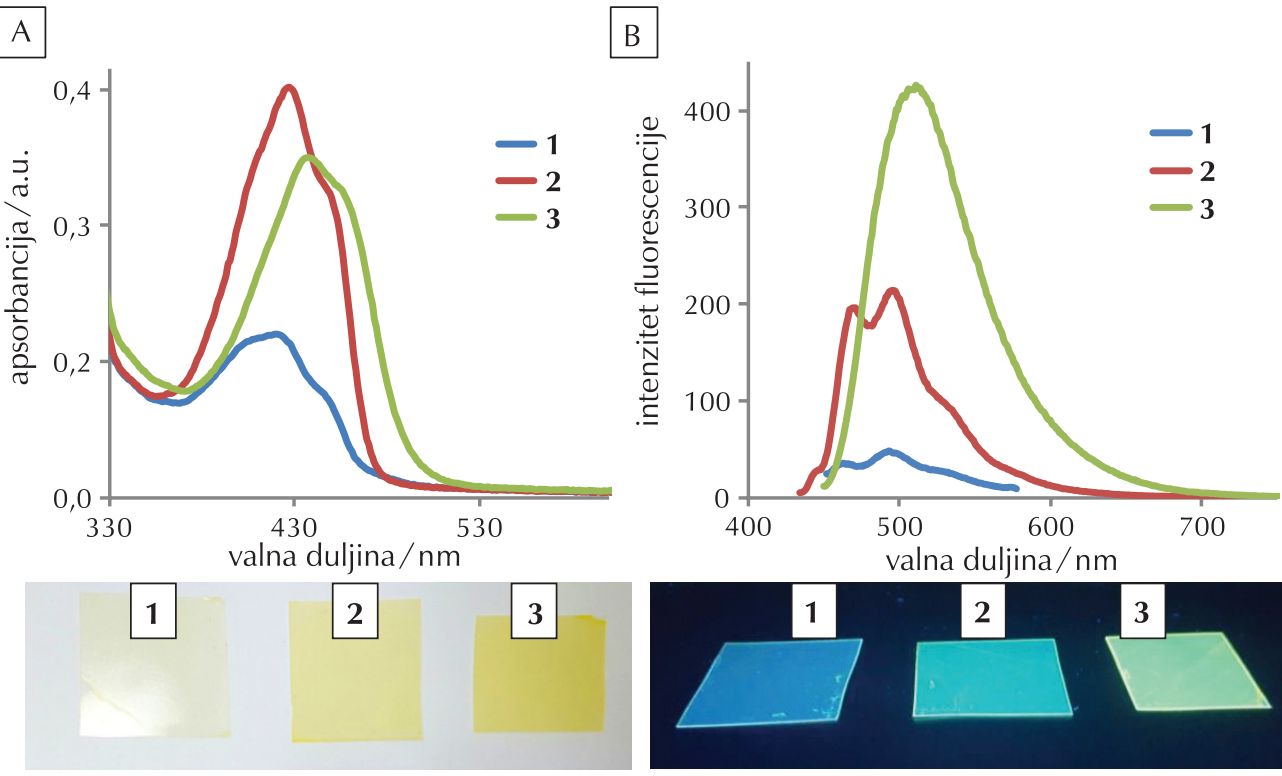

Slika 3 - Apsorpcijski (A) i emisijski (B) spektri Schiffovih baza benzimidazola 1-3 u plastificiranim PVC matricama (slike su snimljene pod dnevnim i UV svjetlom valne duljine $I=366 \mathrm{~nm}$ )

Fig. 3 - Absorption (A) and emission (B) spectra of benzimidazole Schiff bases 1-3 in plasticised PVC thin films (photographs taken in daylight and under UV lamp with wavelength $/=366 \mathrm{~nm}$ )

2-benzimidazolnih i 2-benzotiazolnih heteroaromatskih karboksaldehida i selektivno vezanje nekih ispitivanih derivata u mali utor i A-T područje DNK (slika 2). ${ }^{25,26}$

Benzamidni derivati s aromatskom ili benzotiazolnom i/ ili benzimidazolnom jezgrom supstituirani s promjenjivim brojem metoksi i hidroksilnih skupina pokazali su značajnu redukcijsku aktivnost, kao i slobodno radikalnu aktivnost uklanjanja koja jako ovisi o broju i tipu supstituenata. ${ }^{27,28}$ Dodatno, derivati supstituirani amidinskim grupama smještenim na benzimidazolskoj ili benzotiazolskoj jezgri izravno vezanoj na fenilni prsten posjeduju obećavajuću antioksidativnu aktivnost potvrđujući tako antioksidativni potencijal i reducirajuću aktivnost kationskih amidino supstituiranih derivata. ${ }^{29}$ Jedan dio istraživanja ove istraživačke grupe usmjeren je i na ispitivanje spektroskopskih i elektrokemijskih karakteristika derivata benzimidazola i benzimidazo[1,2-a]kinolina kao potencijalnih kemijskih senzora za detekciju kationa i/ili pH u otopinama i polimernim matricama u sklopu istraživačkog HRZZ projekta pod imenom Design and Synthesis of Novel Nitrogen-Containing Heterocyclic Fluorophores and Fluorescent Nanomaterials for $\mathrm{pH}$ and Metal-Ion Sensing voditelja dr. sc. R. Vianella s Instituta Ruđer Bošković. ${ }^{30-32}$ 
Tijekom navedenog projekta sintetizirat će se mala biblioteka derivata benzazola, a dodatno će to zajedničko istraživanje rezultirati optimizacijom benzazolskog skeleta, što bi trebalo osigurati bolju aktivnost i optimirana svojstva odabranih vodećih spojeva kao antioksidativnih agensa za antitumorsku terapiju. U predloženom projektu kombiniraju se istraživačke vještine i stručnost multidisciplinarnog suradničkog tima, koji se sastoji od sintetskih kemičara, računalnih kemičara, molekularnih biologa i biotehnologa s osnovnim ciljem predloženog projekta koji uključuje razvoj novih i učinkovitijih derivata benzazola.

\section{- prof. dr. sc. Irena Škorić, doc. dr. sc. Dragana Vuk, Ana Ratković, mag. appl. chem.}

Kao nastavak na dugogodišnju problematiku koja je obuhvaćala, među ostalim, i istraživanje reaktivnosti u pobuđenom stanju raznih $o$-vinil-heterostilbena i diheterostilbena, ${ }^{33}$ u proteklom desetljeću istraživanje kojim se bavi prof. dr. sc. I. Škorić i suradnice usmjereno je na učinkovitiju fotokemijsku sintezu benzobiciklo[3.2.1]oktadienskog skeleta iz visoko konjugiranih početnih supstrata i njegovu daljnju funkcionalizaciju. Općenito, biciklo[3.2.1]oktanski sustav uobičajena je podjedinica u mnogim prirodnim spojevima. ${ }^{34}$ Ta struktura temeljna je jedinica brojnih važnih biološki aktivnih prirodnih spojeva ili njihovih metabolita. ${ }^{35,36}$ Još važnije, spojevi s biciklo[3.2.1]-skeletom predstavljaju skupinu snažnih inhibitora transportera dopamina i serotonina i imaju ključnu ulogu u liječenju bolesti središnjeg živčanog sustava (CNS) i Alzheimerove bolesti (AD). ${ }^{37-39} \mathrm{Na}$ osnovi primarnih bioloških rezultata i izračunatih ADME svojstava (engl. Absorption, Distribution, Metabolism and Excretion), molekule s najboljom inhibicijom enzima kolinesteraza, enzima koji kontroliraju prijenos živčanih impulsa, odabiru se za daljnju optimizaciju kako bi se dobili spojevi s poboljšanim biološkim svojstvima. Općenito, najbolja farmakoterapija kod AD su, zasada, inhibitori kolinesteraza.

Sinteza spojeva koji sadrže biciklo[3.2.1]oktanski i biciklo[3.2.1]oktenski skelet dobro je dokumentirana u literaturi. ${ }^{40}$ Biciklo[3.2.1]-skelet može se dobiti različitim sintetskim putevima, od kojih je najjednostavniji upravo fotokemijski pristup u klasičnom fotokemijskom reaktoru. ${ }^{41,42} \mathrm{Na}$ taj način dobivena je čitava knjižnica policikličkih spojeva primjenom fotokemijske sinteze u tradicionalnom fotoreaktoru. Fotokemija u protočnim sustavima ${ }^{43-45}$ u protekle je dvije godine primijenjena prvi put za sintezu benzobiciklo[3.2.1]oktadiena. U usporedbi s klasičnim reaktorom, reakcija provedena u protočnom fotoreaktoru pokazala je bolje rezultate, kako u povećanju iskorištenja i produktivnosti tako i u smanjenju vremena provedbe reakcije. ${ }^{46}$ Ta metoda je zbog navedenih prednosti prepoznata za daljnja istraživanja kao ključni alat u sintezi biciklo[3.2.1] oktadienskog skeleta kao i njegovoj funkcionalizaciji.

Benzobiciklo[3.2.1]oktadieni sintetizirani u protočnom fotoreaktoru (slika 4) testiraju se na biološku aktivnost i lipofilnost. Općenito, temeljne fizikalno-kemijske značajke CNS-lijekova povezane su s njihovom sposobnošću da prodiru kroz krvno-moždanu barijeru i pokazuju CNS-aktivnost. Dobiveni spojevi pokazuju dobru penetraciju kroz krvno-moždanu barijeru. Nekima od odabranih policikličkih fotoprodukata ispitana je inhibicijska aktivnost prema acetil- i butirilkolinesterazama, ${ }^{47,48}$ a pokazali su visok stupanj inhibicije kolinesteraza. Mjerenja eksperimentalnih fizikalno-kemijskih i ADME svojstava dobivenih fotoprodukata, njihove biološke aktivnosti i inhibicijske aktivnosti prema kolinesterazama također su vrlo obećavajuća. Obećavajući rezultati ispitivanja biološke aktivnosti potiču na nastavak funkcionalizacije ${ }^{49}$ u smjeru priprave novih amino-, oksimskih, eterskih, esterskih te hidroksilnih i acilnih derivata benzobiciklo[3.2.1]-skeleta (slika 5.).

Novi spojevi koji su potencijalni aktivni modulatori aktivnosti acetilkolinesteraze i butirilkolinesteraze razvijaju se u suradnji s dr. sc. Zrinkom Kovarik (Institut za medicinska istraživanja i medicinu rada), pri čemu se temeljem interpretacije bioloških podataka dolazi do prijedloga za dizajn novih spojeva za moguću medicinsku primjenu.

Funkcionalizacija benzobiciklo[3.2.1]-skeleta vrlo se selektivno postiže i primjenom metaliranih porfirina kao fotokatalizatora. Na velikom broju fotoprodukata provedena je fotokatalitička oksigenacija koristeći anionske i kationske $\mathrm{Mn}(\mathrm{III})$-porfirinske komplekse kao izrazito korisne katalizatore. ${ }^{50,51}$ Funkcionalizacijom na taj su način dobiveni novi policiklički epoksidi, enedioni, ketoni, alkoholi i/ili hidroperoksidi, ovisno o vrsti upotrijebljenog katalizatora, anionskog ili kationskog. U okviru višegodišnje suradnje s grupom prof. O. Horvátha (University of Pannonia) ispitano je fotofizikalno ponašanje i Co- i Ni-kompleksa te je potvrđeno da i oni pokazuju karakteristike potencijalno dobrih fotokatalizatora za daljnju funkcionalizaciju fotoprodukata.

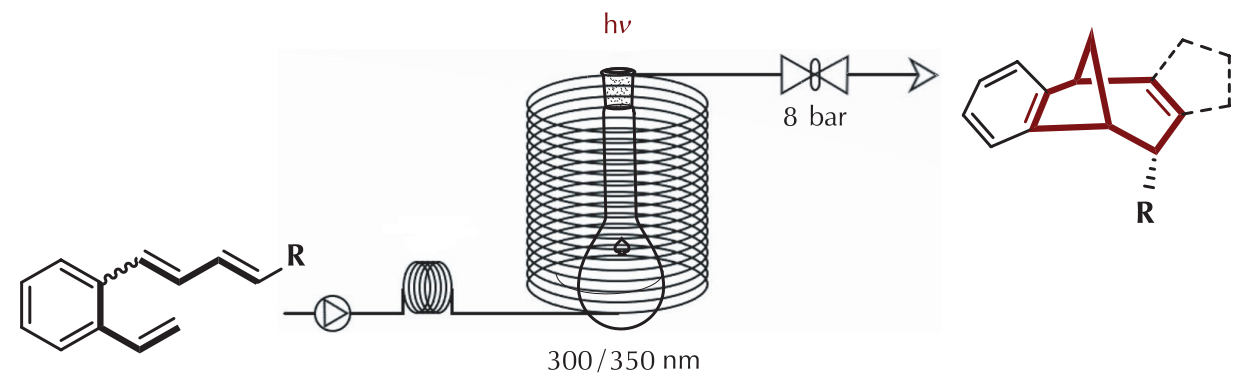

Slika 4 - Primjena protočnog sustava za fotokemijske reakcije

Fig. 4 -Application of flow system for the photochemical reactions 

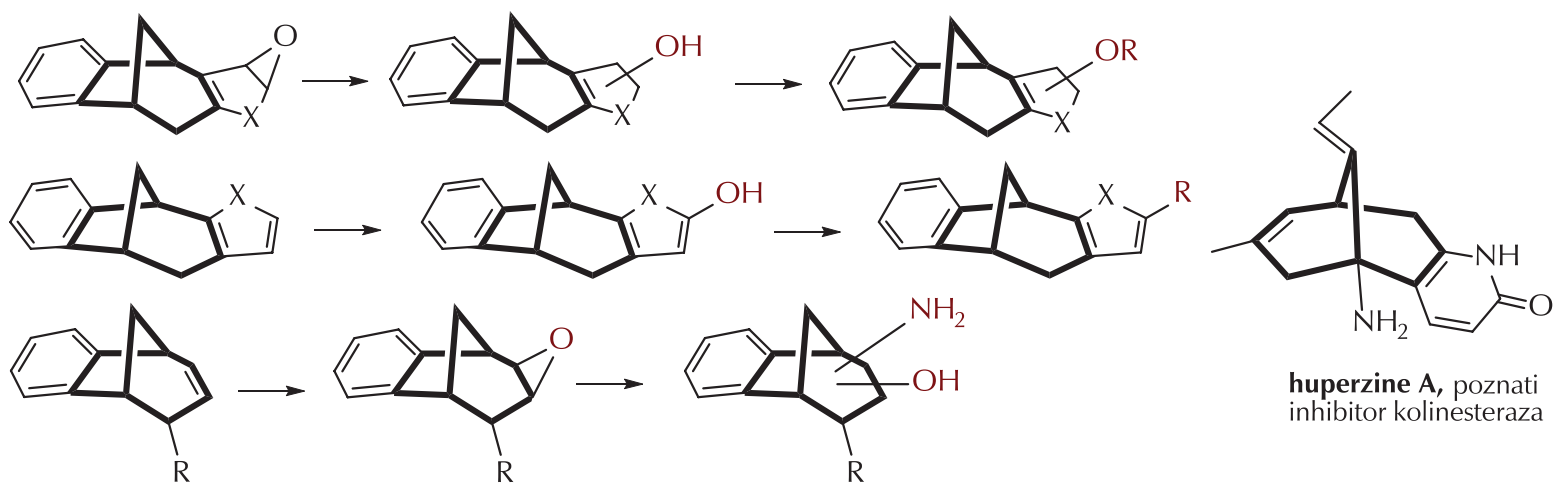

huperzine $A$, poznati inhibitor kolinesteraza

Slika 5 - Funkcionalizacija benzobiciklo[3.2.1]-skeleta

Fig. 5 - Functionalisation of the benzobicyclo[3.2.1]-skeleton
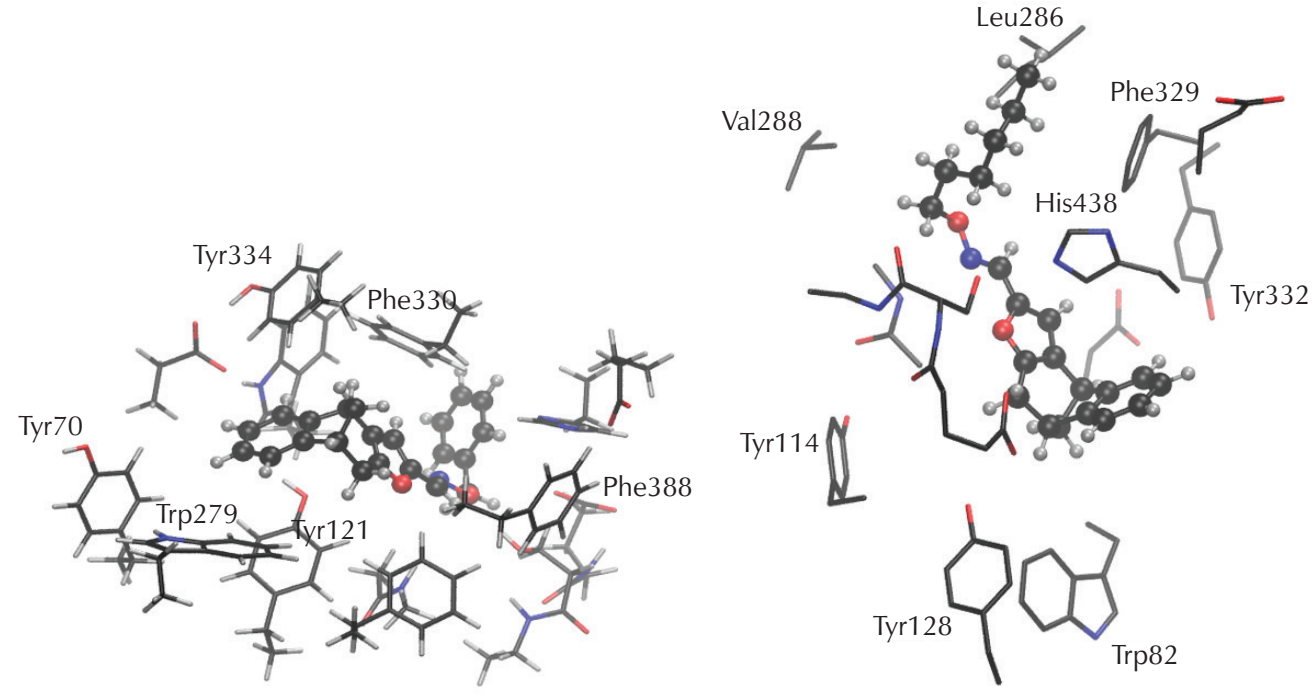

Slika 6 - Optimirane strukture odabranih kompleksa [aktivno mjesto AChE (lijevo) i BChE (desno) sintetizirane molekule]

Fig. 6 - Optimised structures of the selected complexes [AChE (left) and BChE active centre (right) synthesised molecules]

Pri kreiranju strategije za sintezu novih derivata benzobiciklo[3.2.1]-skeleta s potencijalnim bioaktivnim svojstvima provodi se računalno modeliranje mehanizama sinteze, tj. identifikacija svih stupnjeva koji vode do konačnih produkata, što je od iznimne važnosti (dr. sc. D. Barić, Grupa za računalne bioznanosti, IRB). Računalnim modeliranjem reakcijskog mehanizma dolazi se do informacija o brzini svakog od stupnjeva na reakcijskom putu, stabilnosti međuprodukata, mogućim kompeticijskim reakcijama i nastajanju neželjenih međuprodukata, utjecaju različitih otapala na tijek reakcije, utjecaju različitih katalizatora na tijek sinteze te termodinamičkoj stabilnosti konačnih produkata. Dobiveni rezultati omogućavaju odabir optimalnih uvjeta za provedbu sinteze, odnosno ciljano osmišljavanje što efikasnijeg plana priprave za svaku od skupina derivata benzobiciklo[3.2.1]-skeleta. Računalnim metodama određuje se i relativna termodinamička stabilnost kompleksa koji nastaje smještanjem potencijalnog inhibitora u aktivno mjesta enzima acetilkolinesteraze i butirilkolinesteraze, ${ }^{52}$ pri čemu se kao potencijalni inhibitori ispituju novosintetizirani funkcionalizirani fotoprodukti (slika 6). Molekule koje stvaraju stabilnije komplekse trebale bi pokazati jaču sposobnost inhibicije tih dvaju enzima. Važno je naglasiti da je cilj tog pristupa za dobivanje vrijednosti slobodnih energija pri stvaranju kompleksa predvidjeti trend i ponašanje unutar skupa sličnih molekula, što dalje omogućava ciljanu sintezu pogodnih potencijalnih inhibitora kolinesteraza.

Osim navedene problematike, grupa prof. I. Škorić posljednjih godina ostvaruje značajnu znanstvenu interdisciplinarnu suradnju i na polju praćenja sudbine farmaceutika $u$ okolišu, ${ }^{53}$ na fotofizici fotokemijski nereaktivnih konjugiranih heteropolicikličkih spojeva, ${ }^{54}$ na identifikaciji degradacijskih produkata farmaceutika nastalih pri mehanokemijskoj aktivaciji ${ }^{55}$ te fotostabilnosti eteričnih ulja. ${ }^{56}$ 


\section{Literatura \\ References}

1. A. Meščić, A. Šalić, T. Gregorić, B. Zelić, S. Raić-Malić, Continuous flow-ultrasonic synergy in click reactions for the synthesis of novel 1,2,3-triazolyl appended 4,5-unsaturated L-ascorbic acid derivatives, RSC Adv. 7 (2017) 791-800, doi: https://doi.org/10.1039/C6RA25244C.

2. M. Tireli, S. Maračić, S. Lukin, M. Juribašić Kulcsar, D. Žilić, M. Cetina, I. Halasz, S. Raić-Malić, K. Užarević, Solvent-free copper-catalyzed click chemistry for the synthesis of $N$-heterocyclic hybrids based on quinolone and 1,2,3-triazole, Beilstein J. Org. Chem, 13 (2017) 2352-2363, doi: https:// doi.org/10.3762/bjoc.13.232.

3. T. Gregorić, M. Sedić, P. Grbčić, A. Tomljenović Paravić, S. Kraljević Pavelić, M. Cetina, R. Vianello, S. Raić-Malić, Novel pyrimidine-2,4-dione-1,2,3-triazole and furo[2,3-d]pyrimidine-2-one-1,2,3-triazole hybrids as potential anti-cancer agents: Synthesis, computational and X-ray analysis and biological evaluation, Eur. J. Med. Chem. 125 (2017) 12471267, doi: https://doi.org/10.1016/j.ejmech.2016.11.028.

4. A. Bistrović, P. Grbčić, A. Harej, M. Sedić, S. Kraljević Pavelić, S. Koštrun, J. Plavec, D. Makuc, S. Raić-Malić, Small molecule purine and pseudopurine derivatives: synthesis, cytostatic evaluations and investigation of growth inhibitory effect in non-small cell lung cancer A549, J. Enzyme Inhib. Med. Chem. 33 (2018) 271-285, doi: https://doi.org/10.1080/14 756366.2017.1414807.

5. A. Bistrović, A. Harej, P. Grbčić, M. Sedić, S. Kraljević Pavelić, M. Cetina, S. Raić-Malić, Synthesis and anti-proliferative effects of mono- and bis-purinomimetics targeting kinases, Int. J. Mol. Sci. 18 (2017) 2292-2312, doi: https://doi. org/10.3390/ijms18112292.

6. A. Bistrović, L. Krstulović, A. Harej, P. Grbčić, M. Sedić, S. Koštrun, S. Kraljević Pavelić, S. Raić-Malić, Design, synthesis and biological evaluation of novel benzimidazole amidines as potent multi-target inhibitors for the treatment of nonsmall cell lung cancer, Eur. J. Med. Chem. 143 (2018) 16161634, doi: https://doi.org/10.1016/j.ejmech.2017.10.061.

7. T. Gazivoda Kraljević, A. Harej, M. Sedić, S. Kraljević Pavelić, Višnja Stepanić, D. Drenjančević, J. Talapko, S. Raić-Malić, Synthesis, in vitro anticancer and antibacterial activities and in silico Studies of new 4-substituted 1,2,3-triazole-coumarin hybrids, Eur. J. Med. Chem. 124 (2016) 794-808, doi: https://doi.org/10.1016/j.ejmech.2016.08.062.

8. A. Bistrović, L. Krstulović, I. Stolić, D. Drenjančević, J. Talapko, M. Taylor, J. Kelly, M. Bajić, S. Raić-Malić, Synthesis, anti-bacterial and anti-protozoal activities of amidinobenzimidazole derivatives and their interactions with DNA and RNA, J. Enzyme Inhib. Med. Chem. 33 (2018) 1323-1334, doi: https://doi.org/10.1080/14756366.2018.1484733.

9. A. Bistrović Popov, I. Stolić, L. Krstulović, M.C. Taylor, J. M. Kelly, S. Tomić, L. Tumir, M. Bajić, S. Raić-Malić, Novel symmetric bis-benzimidazoles: Synthesis, DNA/RNA binding and antitrypanosomal activity, Eur. J. Med. Chem. 173 (2019) 63-75, doi: https://doi.org/10.1016/j.ejmech.2019.04.007.

10. A. Meščić, A. Harej, M. Klobučar, D. Glavač, M. Cetina, S. Kraljević Pavelić, S. Raić-Malić, Discovery of new acid ceramidase-targeted acyclic 5-alkynyl and 5-heteroaryl uracil nucleosides, ACS Med. Chem. Lett. 6 (2015) 1150-1155, doi: https://doi.org/10.1021/acsmedchemlett.5b00298.

11. S. Maračić, T. Gazivoda Kraljević, H. Čipčić Paljetak, M. Perić, M. Matijašić, D. Verbanac, M. Cetina, S. Raić-Malić, 1,2,3-Triazole pharmacophore-based benzofused nitrogen/sulfur heterocycles with potential anti-Moraxella catarrhalis activity, Bioorg. Med. Chem. 23 (2015) 7448-7463, doi: https:// doi.org/10.1016/j.bmc.2015.10.042.
12. S. Raić-Malić, A. Meščić, Recent Trends in 1,2,3-Triazolo-Nucleosides as Promising Anti-Infective and Anticancer Agents, Curr. Med. Chem. 22 (2015) 1462-1499, doi: https://doi.or g/10.2174/0929867322666150227150127.

13. A. Meščić Macan, T. Gazivoda Kraljević, S. Raić-Malić, Therapeutic perspective of vitamin $\mathrm{C}$ and its derivatives, Antioxidants 8 (2019) 247-283, doi: https://doi.org/10.3390/ antiox8080247.

14. K. Brajša, I. Vujasinović, D. Jelić, M. Trzun, I. Zlatar, G. Karminski-Zamola, M. Hranjec, Antitumor activity of amidino-substituted benzimidazole and benzimidazo[1,2-a]quinoline derivatives tested in 2D and 3D cell culture systems, J. Enzyme Inhib. Med. Chem. 31 (2016) 1139-1145, doi: https://doi.org/10.3109/14756366.2015.1101093.

15. N. Perin, J. Alić, S. Liekens, A. Van Aerschot, P. Vervaeke, B. Gadakh, M. Hranjec, Different positions of amide side chains on the benzimidazo[1,2-a]quinoline skeleton strongly influenced biological activity, New J. Chem. 42 (2018) 70967104, doi: https://doi.org/10.1039/C8NJ00416A.

16. N. Perin, R. Nhili, K. Ester, W. Laine, G. Karminski-Zamola, M. Kralj, M. H. David-Cordonnier, M. Hranjec, Synthesis, antiproliferative activity and DNA binding properties of novel 5-aminobenzimidazo[1,2-a]quinoline-6-carbonitriles, Eur. J. Med. Chem. 80 (2014) 218-227, doi: https://doi. org/10.1016/j.ejmech.2014.04.049.

17. L. Racané, M. Sedić, N. Ilić, M. Aleksić, S. Kraljević Pavelić, G. Karminski-Zamola, Novel 2-Thienyl- and 2-Benzothienyl-Substituted 6-(2-Imidazolinyl)Benzothiazoles: Synthesis, in vitro Evaluation of Antitumor Effects and Assessment of Mitochondrial Toxicity, AntiCancer Agents Med. Chem. 17 (2017) 57-66, doi: https://doi.org/10.2174/187152061566 6160504094753.

18. N. Perin, R. Nhili, M. Cindrić, B. Bertoša, D. Vušak, I. Martin-Kleiner, W. Laine, G. Karminski-Zamola, M. Kralj, M. H. David-Cordonnier, M. Hranjec, Amino substituted benzimidazo[1, 2-a]quinolines: Antiproliferative potency, 3D QSAR study and DNA binding properties, Eur. J. Med. Chem. 122 (2016) 530-545, doi: https://doi.org/10.1016/j.ejmech.2016.07.007.

19. D. Vušak, N. Perin, I. Martin-Kleiner, M. Kralj, G. Karminski-Zamola, M. Hranjec, B. Bertoša, Synthesis and antiproliferative activity of amino substituted benzimidazo[1,2-a] quinolines as mesylate salts designed by 3D-QSAR analysis, Mol. Divers. 21 (2017) 621-636, doi: https://doi. org/10.1007/s11030-017-9753-8.

20. I. O. de Souza, C. M. L. Schrekker, W. Lopes, R. Orru, M. Hranjec, N. Perin, M. Machado, L. F. Oliveira, R. K. Donato, V. Stefani, A. M. Fuentefria, H. S. Schrekker, Bifunctional Fluorescent Benzimidazo[1,2-a]quinolines for Candida spp. Biofilm Detection and Biocidal Activity, J. Photochem. Photobiol. B 163 (2016) 319-326, doi: https://doi.org/10.1016/j. jphotobiol.2016.08.037.

21. M. Hranjec, E. Horak, D. Babić, S. Plavljanin, Z. Srdović, I. Murković Steinberg, $R$ Vianello, N. Perin, Fluorescent benzimidazo[1,2-a]quinolines: Synthesis, spectroscopic and computational studies of protonation equilibria and metal ion sensitivity, New J. Chem. 41 (2017) 358-371, doi: https://doi.org/10.1039/C6NJ02268E.

22. M. Hranjec, E. Horak, M. Tireli, G. Pavlović, G. Karminski-Zamola, Synthesis, crystal structure and spectroscopic study of novel benzimidazoles and benzimidazo[1,2a]quinolines as potential chemosensors for different cations, Dyes Pigments 95 (2012) 644-656, doi: https://doi.org/10.1016/j. dyepig.2012.05.024.

23. M. Tireli, K. Starčević, T. Martinović, S. Kraljević Pavelić, G. Karminski-Zamola, M. Hranjec, Antioxidative and antiprolif- 
erative activities of novel pyrido[1,2-a]benzimidazoles, Mol. Divers. 21 (2017) 201-210, doi: https://doi.org/10.1007/ s11030-016-9702-y.

24. N. Perin, K. Bobanović, I. Zlatar, D. Jelić, V. Kelava, S. Koštrun, V. Gabelica Marković, K. Brajša, M. Hranjec, Antiproliferative activity of amino substituted benzo[b]thieno[2,3-b]pyrido[1,2-a]benzimidazoles explored by 2D and 3D cell culture system, Eur. J. Med. Chem. 125 (2017) 722-735, doi: https://doi.org/10.1016/j.ejmech.2016.09.084.

25. M. Cindrić, S. Jambon, A. Harej, S. Depauw, M. David-Cordonnier, S. Kraljević Pavelić, G. Karminski-Zamola, M. Hranjec, Novel amidino substituted benzimidazole and benzothiazole benzo[b]thieno-2-carboxamides exert strong antiproliferative and DNA binding properties, Eur. J. Med. Chem. 136 (2017) 468-479, doi: https://doi.org/10.1016/j. ejmech.2017.05.014.

26. M. Cindrić, M.; Perić, M. Kralj, I. Martin-Kleiner, M. H. David-Cordonnier, H. Čipčić Paljetak, M. Matijašić, D. Verbanac, G. Karminski-Zamola, M. Hranjec, Antibacterial and antiproliferative activity of novel 2-benzimidazolyl and 2-benzothiazolyl substituted benzo[b]thieno-2-carboxamides, Mol. Divers. 22 (2018) 637-646, doi: https://doi.org/10.1007/ s11030-018-9822-7.

27. M. Cindrić, I. Sović, I. Martin-Kleiner, M. Kralj, T. Mašek, M. Hranjec, K Starčević, Synthesis, antioxidative and antiproliferative activity of methoxy amidino substituted benzamides and benzimidazoles, Med. Chem. Res. 26 (2017) 2024 2037, doi: https://doi.org/10.1007/s00044-017-1912-z.

28. N. Perin, P. Roškarić, I. Sović, I. Boček, K. Starčević, M. Hranjec, R. Vianello, Amino-Substituted Benzamide Derivatives as Promising Antioxidant Agents: A Combined Experimental and Computational Study, Chem. Res. Toxicol. 31 (2018) 974-998, doi: https://doi.org/10.1021/acs.chemrestox $.8 \mathrm{~b} 00175$.

29. I. Sović, M. Cindrić, N. Perin, I. Boček, I. Novaković, A. Damjanović, T. Stanojković, M. Zlatović, M. Hranjec, B. Bertoša, Biological potential of novel methoxy and hydroxy substituted heteroaromatic amides designed as promising antioxidative agents: Synthesis, 3D-QSAR analysis and biological activity, Chem. Res. Toxicol. (2019), prihvaćen za objavljivanje, doi: https://doi.org/10.1021/acs.chemrestox.9b00256.

30. E. Horak, M. Hranjec, R. Vianello, I. Murković Steinberg, Reversible $\mathrm{pH}$ switchable aggregation-induced emission of self-assembled benzimidazole-based acrylonitrile dye in aqueous solution, Dyes Pigments 142 (2017) 108-115, doi: https://doi.org/10.1016/j.dyepig.2017.03.021.

31. E. Horak, P. Kassal, M. Hranjec, I. Murković Steinberg, Benzimidazole functionalised Schiff bases: novel $\mathrm{pH}$ sensitive fluorescence turn-on chromoionophores for ion-selective optodes, Sens. Actuator B-Chem. 258 (2018) 415-423, doi: https://doi.org/10.1016/j.snb.2017.11.121.

32. I. Novak Jovanović, D. Jadreško, A. Miličević, M. Hranjec, N. Perin, An electrochemical study on the redox chemistry of cyclic benzimidazole derivatives with potent anticancer activity, Electrochim. Acta 297 (2019) 452-462, doi: https:// doi.org/10.1016/j.electacta.2018.11.198.

33. I. Šagud, I. Škorić, M. Šindler-Kulyk, Excited state transformations of heterostilbenes; pathways to polycyclic skeleta, Comptes rendus Chimie 21 (2018) 1043-1052, doi: https:// doi.org/10.1016/j.crci.2018.09.008.

34. a) A. Abad, C. Agulló A. C. Cuñat, I. de Alfonso, I. Navarro, N. Vera, Synthesis of Highly Functionalised Enantiopure Bicyclo[3.2.1]- octane Systems from Carvone, Molecules 9 (2004) 287-299, doi: https://doi.org/10.3390/90500287; b) J. A. Miller, J. Harris, A. A. Miller, G. M. Ullaha, G. M. Welsh, Synthesis of 8-substituted bicyclo[3.2.1] octane-6-carboxyl- ic acids and anti-convulsant properties of the corresponding amides, Tetrahedron Lett. 45 (2004) 4323-4327, doi: https://doi.org/10.1016/j.tetlet.2004.04.007.

35. C. V. Kavitha, M. Nambiar, P. B. Narayanaswamy, E. Thomas, U. Rathore, C. S. A. Kumar, B. Choudhary, K. S. Rangappa, S. C. Raghavan, Propyl-2-(8-(3,4-Difluorobenzyl)-2',5'-Dioxo-8-Azaspiro[Bicyclo[3.2.1] Octane-3,4'-Imidazolidine]-1'-yl) Acetate Induces Apoptosis in Human Leukemia Cells through Mitochondrial Pathway following Cell Cycle Arrest, PlosOne 8 (2013) 69103, doi: https://doi.org/10.1371/ journal.pone.0069103.

36. V. Mascitti, C. Preville, Stereoselective Synthesis of a Dioxa-bicyclo[3.2.1] octane SGLT2 Inhibitor, Org. Lett. 12 (2010) 2940-2943, doi: https://doi.org/10.1021/ol100940w.

37. A. Yu. Mandzhulo, N. A. Mel'nichuk, V. N. Fetyukhin, M. V. Vovka, Trifluoroacetylation of $\mathrm{N}$-Substituted $1 \mathrm{H}-1,2-\mathrm{Di}-$ azaphenalenes of the Naphthalene and Acenaphthene Series, Russ. J. Org. Chem. 52 (2016) 87-91, doi: https://doi. org/10.1134/S107042801901010X.

38. P. C. Meltzer, P. Blundell, Y. F. Yong, Z. Chen, C. George, M. D. Gonzalez, B. K. Madras, 2-Carbomethoxy-3-aryl-8-bicyclo[3.2.1]octanes: Potent Non-Nitrogen Inhibitors of Monoamine Transporters, J. Med. Chem. 43 (2000) 2982-2991, doi: https://doi.org/10.1021/jm000191g.

39. M. Presset, Y. Coquerel, J. Rodriguez, Syntheses and Applications of Functionalized Bicyclo[3.2.1]octanes: Thirteen Years of Progress, Chem. Rev. 113 (2013) 525-595, doi: https:// doi.org/10.1021/cr200364p.

40. M. Šindler-Kulyk, L. Špoljarić, Ž. Marinić, Photochemistry of beta-(2-Furyl)Substituted o-Divinylbenzenes, Heterocycles 29 (1989) 679-682, doi: https://doi.org/10.3987/COM-894629.

41. I. Škorić, M. Šmehil, Ž. Marinić, K. Molčanov, B. Kojić-Prodić, M. Šindler-Kulyk, Photochemistry of $\omega$-(o-vinylphenyl)- $\omega$ '-(phenyl / 2-furyl) butadienes: New approach to 4- substituted benzobicyclo[3.2.1]octadienes, J. Photochem. Photobiol. 207 (2009) 190-196, doi: https://doi. org/10.1016/j.jphotochem.2009.07.008.

42. I. Šagud, M. Levačić, Ž. Marinić, I. Škorić, Formation of polycyclic skeleton via photochemical transformations of new pyridyl- and thienyl-butadiene derivatives, Eur. J. Org. Chem. 26 (2017) 3787-3794, doi: https://doi.org/10.1002/ ejoc. 201700481.

43. M. B. Plutschack, B. Pieber, K. Gilmore, P. H. Seeberger, The Hitchhiker's Guide to Flow Chemistry, Chem. Rev. 117 (2017) 11796-11893, doi: https://doi.org/10.1021/acs. chemrev.7b00183.

44. E. N. DeLaney, D. S. Lee, L. D. Elliott, J. Jin, K. I. Booker-Milburn, M. Poliakoff, M. W. George, A laboratory-scale annular continuous flow reactor for UV photochemistry using excimer lamps for discrete wavelength excitation and its use in a wavelength study of a photodecarboxlyative cyclisation, Green Chem. 19 (2017) 1431-1438, doi: https://doi. org/10.1039/C6GC02888H.

45. K. Loubièrea, M. Oelgemöllerc, T. Ailleta, O. Dechy-Cabareta, L. Prata, Continuous-flow photochemistry: A need for chemical engineering, Chemical Engineering and Processing 104 (2016) 120-132, doi: https://doi.org/10.1016/j. cep.2016.02.008.

46. A. Ratković, Ž. Marinić, I. Škorić, Flow-photochemical synthesis of the functionalized benzobicyclo[3.2.1]octadiene skeleton, J. Mol. Struct. 1168 (2018) 165-174, doi: https:// doi.org/10.1016/j.molstruc.2018.05.027.

47. I. Šagud, I. Škorić, D. Vuk, A. Ratković, F. Burčul, Acetyl- and butyrylcholinesterase inhibitory activity of selected photochemically synthesized polycycles, Turk. J. Chem. 43 (2019) 
1170-1182, doi: https://doi.org/10.3906/kim-1903-74.

48. I. Šagud, I. Škorić, F. Burčul, Naphthoxazoles and heterobenzoxazoles: cholinesterase inhibition andantioxidant activity, Turk. J. Chem. 43 (2019) 118-124, doi: https://doi. org/10.3906/kim-1807-133.

49. A. Ratković, V. Kelava, Ž. Marinić, I. Škorić, Buchwald-Hartwig amination of the chloro substituted benzobicyclo[3.2.1] octadiene skeleton using primary benzylic amines, J. Mol. Struct. 1179 (2019) 597-607, doi: https://doi.org/10.1016/j. molstruc.2018.11.057.

50. I. Kikaš, O. Horváth, I. Škorić, Functionalization of the benzobicyclo[3.2.1]octadiene skeleton via photocatalytic and thermal oxygenation of a furan derivative, Tetrahedron Lett. 52 (2011) 6255-6259, doi: https://doi.org/10.1016/j.tetlet.2011.09.076.

51. D. Vuk, O. Horváth, I. Škorić, New Functionalized Polycycles Obtained by Photocatalytic Oxygenation Using Mn(III) Porphyrins in Basic Media, Catalysts 9 (2019) 304-315, doi: https://doi.org/10.3390/catal9040304.

52. P. E. M. Siegbahn, F. Himo, The quantum chemical cluster approach for modeling enzyme reactions, Comput. Mol. Sci. 1 (2011) 323-333, doi: https://doi.org/10.1002/wcms.13.

53. D. Dabić, S. Babić, I. Škorić, The role of photodegradation in the environmental fate of hydroxychloroquine, Chemosphere 230 (2019) 268-277, doi: https://doi. org/10.1016/j.chemosphere.2019.05.032.

54. B. Carlotti, A. Cesaretti, G. Cacioppa, F. Elisei, I. Odak, I. Škorić, A. Spalletti, Fluorosolvatochromism and hyperpolarizability of one-arm and two-arms nitro-compounds bearing heterocyclic rings, J. Photochem. Photobiol. A, Chemistry 368 (2019) 190-199, doi: https://doi.org/10.1016/j.jphotochem.2018.09.043.

55. I. Šagud, D. Zanolla, B. Perissutti, N. Passerini, I. Škorić, Identification of degradation products of praziquantel during the mechanochemical activation, J. Pharm. Biomed. Analysis, 159 (2018) 291-295, doi: https://doi.org/10.1016/j. jpba.2018.07.002.

56. I. Odak, I. Škorić, D. Grbavac, A. Ratković, I. Šagud, Alteration in the Chemical Composition of Immortelle, Silver Fir and Prickly Juniper Essential Oils Induced by Light, Acta Chim. Slov. (2019), prihvaćen za objavljivanje. 


\section{SUMMARY}

\section{Scientific Research Activities of the Department of Organic Chemistry in the Period 2009-2019 \\ Tatjana Gazivoda Kraljević, Marijana Hranjec, Silvana Raić-Malić, Irena Škorić, and Dragana Vuk*}

Since its establishment in 1922 by Professor Ivan Marek and through the work of Nobel Prize winner Vladimir Prelog, the Department of Organic Chemistry, Faculty of Chemical Engineering and Technology, University of Zagreb, showed strong impact, not only on scientific activities of the Department, but on the entire Croatian scientific community, especially in the domain of organic synthetic and medicinal chemistry. Preparative organic chemistry, thanks to the work of Professor Prelog (1935-1941), has remained the main scientific research activity in the Department. Since the formation of the Department of Organic Chemistry, research work in the field of synthetic organic and medicinal chemistry, as well as photochemistry, is carried out in its laboratories, scientific degrees are achieved and numerous organic chemists have been educated, many of whom are now recognised scientists in Croatia and worldwide.

\section{Keywords}

Department of Organic Chemistry, synthetic organic chemistry, medicinal chemistry, organic photochemistry

Department of Organic Chemistry Faculty of Chemical Engineering and Review Technology, University of Zagreb Marulićev trg 20, 10000 Zagreb, Croatia 